\title{
SISTEM PREDIKSI KUALITAS SANTAN KELAPA MENGGUNAKAN NEAREST MEAN CLASSIFIER (NMC)
}

\author{
Masparudin, Abdullah, Usman \\ Program Studi Sistem Informasi, Fakultas Teknik dan Ilmu Komputer, Universitas Islam Indragiri \\ Jl. Provinsi Parit 1 Tembilahan Hulu Indragiri Hilir Riau \\ Email: masfaruddin.ibnu.mahmud@gmail.com,abdialam@gmail.com, \\ usmanovsky13411@gmail.com
}

\begin{abstract}
Coconut milk is one of the main ingredients that is always used as an ingredient for all types of food. Quality is crucial in choosing coconut milk. However, identifying the quality of coconut milk in plain view is not efficient. It occurs because it is difficult to distinguish which coconut milk is pure and which one is mixed with water. The purpose of this study was to build a quality detection system for coconut milk-based on the color of the coconut milk. The classification algorithm used is the nearest mean classifier (NMC). This method calculates the distance of the image input vector to each class mean of the training image. The closest distance is the basis for determining the results of the classification. The evaluation uses the holdout validation method using a total of 135 images with a ratio of 2/3 for sample data and 1/3 for test data. The evaluation was carried out using 3 types of smartphone cameras, namely 1 Xiaomi Mi 8 Lite, 2 Oppo 77 cameras, and 3 Samsung Galaxy J3 Pro cameras. In testing, the first camera has an accuracy rate of $86.66 \%$ compared to camera 2 with an accuracy of $60 \%$ and camera 3 with an accuracy of $46 \%$.
\end{abstract}

Keywords: android, coconut milk quality detection, nearest mean classifier (NMC), RGB color

\begin{abstract}
ABSTRAK
Santan kelapa adalah salah satu bahan pokok yang selalu dijadikan bahan untuk segala jenis makanan. Kualitas menjadi hal yang penting dalam pemilihan santan kelapa. Bagaimanapun juga pengidentifikasian kualitas santan secara manual tidak efisien, hal ini terjadi karena sulitnya membedakan mana santan yang murni dan mana santan yang bercampur dengan air. Tujuan penelitian ini adalah membangun sistem deteksi kualitas santan berdasarkan warna santan. Algoritma klasifikasi yang digunakan adalah nearest mean classifier (NMC), Metode ini menghitung jarak vektor input citra ke masing-masing mean kelas dari citra latih, jarak terdekat merupakan dasar dalam menentukan hasil dari klasifikasi. Evaluasi menggunakan metode validasi holdout menggunakan total 135 citra dengan perbandingan 2/3 untuk data sampel dan 1/3 digunakan untuk data uji. Evaluasi dilakukan dengan 3 menggunakan 3 jenis kamera smartphone yaitu kamera 1 Xiaomi Mi 8 Lite, kamera 2 Oppo F7, dan kamera 3 Samsung Galaxy J3 Pro. Pada pengujian kamera pertama memiliki tingkat akurasi tertinggi yaitu 86,66\% dibandingkan dengan kamera 2 dengan akurasi $60 \%$ dan kamera 3 dengan akurasi $46 \%$.
\end{abstract}

Kata Kunci: android, deteksi kualitas santan, nearest mean classifier (NMC), warna RGB.

\section{PENDAHULUAN}

Kelapa (cocos nucifera) adalah anggota tunggal dalam marga cocos dari suku aren-arenan atau Arecaceae. Kelapa terdiri dari bagian sabut, bagian mesokarp yang berupa serat-serat kasar. Daging buah kelapa merupakan salah satu bagian yang paling bernilai ekonomi dan banyak digunakan oleh masyarakat maupun industri. Daging buah kelapa dapat diolah menjadi kopra kemudian diproses lebih lanjut menjadi minyak. Selain itu daging buah kelapa dapat pula diolah menjadi kelapa parut dan diperas menjadi santan. Santan kelapa merupakan emulsi minyak kelapa dalam air, yang berwarna putih, diperoleh dengan cara memeras daging kelapa segar yang sudah diparut atau dihancurkan dengan atau tanpa penambahan air. Gambar 1 menunjukkan kelapa parut yang diperas menjadi santan. 


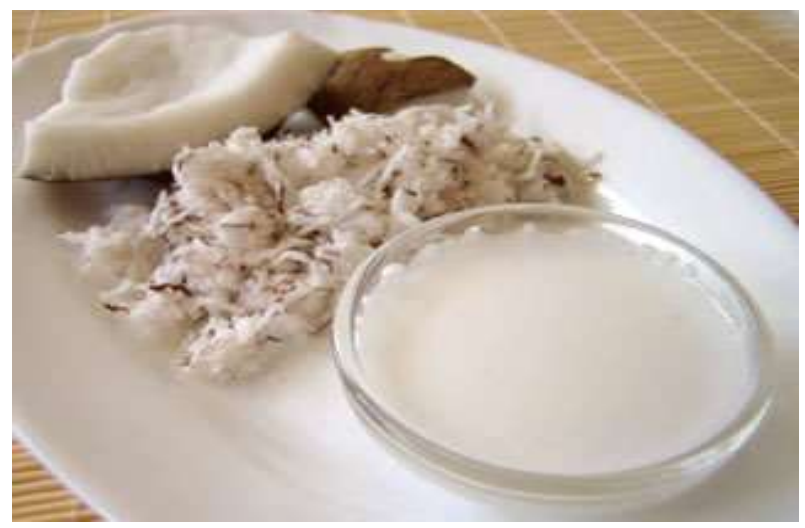

Gambar 1. Santan Kelapa

Pengidentifikasian kualitas santan secara kasat mata tidaklah efisien. Warna santan dipengaruhi oleh kadar air yang telah dicampurkan pada santan kelapa. Bagaimanapun juga sulit membedakan mana santan murni dan santan yang telah dicampur air. Hal ini disebabkan oleh keterbatasan mata untuk membedakan perbedaan warna objek yang mempunyai kemiripan yang besar. Oleh karena itu diharapkan teknologi citra digital dan teknik klasifikasi menggunakan teknologi informasi dapat membantu dalam mendeteksi kualitas santan.

Citra digital merupakan image yang telah didigitalisasikan baik koordinat spasialnya atau tingkat intensitasnya [1]. Citra digital mudah diolah dan disimpan dalam media penyimpanan seperti memori komputer, hard disk atau media lain. Pada citra digital dapat dilakukan klasifikasi berdasarkan fitur tertentu menggunkan algoritma tertentu. Nearest mean classifier (NMC) [2] merupakan salah satu algoritma klasifikasi. NMC merupakan pemilah linear sederhana yang menggunakan kemiripan antar pola untuk melakukan klasifikasi. Metode ini disebut juga minimum Euclidean distance classifier. NMC telah berhasil diterapkan pada masalah klasifikasi dan menunjukkan hasil yang baik. Metode ini mudah dimengerti dan mudah diimplementasikan karena tidak ada asumsi tentang distribusi data dalam ruang fitur.

Pada penelitian ini dibangun aplikasi sistem klasifikasi kualitas santan kelapa berdasarkan warna red green blue (RGB) [3] menggunakan citra digital. Akuisisi citra dilakukan dengan menggunakan smartphone, kemudian dilakukan proses ekstraksi fitur. Proses ekstraksi fitur menghasilkan data berupa nilai mean RGB dari masing-masing kelas. Nilai sampel data tersebut disimpan dalam database Firebase secara online. Algoritma nearest mean classifier (NMC) digunakan dalam proses klasifikasi. Pada client side algoritma perhitungan NMC diletakkan, sedangkan knowledge database tersedia on line menggunakan firebase [4]. Sistem ini diharapkan memberikan solusi untuk pendeteksian kualitas santan kelapa dengan dengan pemanfaatan teknologi informasi atau komputerisasi.

\section{TINJAUAN PUSTAKA}

Beberapa penelitian berkaitan dengan prediksi kualitas objek sudah pernah dilakukan. Meskipun tujuannya sama untuk prediksi namun objek yang diteliti berbeda-beda. Begitu pula fitur yang digunakan juga beragam mulai dari warna, bentuk tekstur dan lainnya. Selain itu juga digunakan berbagai macam teknik klasifikasi. Pada teknik klasifikasi yang menggunakan dasar kemiripan juga menggunakan ukuran jarak kemiripan yang berbeda-beda. Pada bagian tinjauan pustaka ini beberapa penelitian dilakukan review.

Penelitian tentang identifikasi jenis cabai dilakukan oleh [5]. Pada penelitian tersebut klasifikasi dilakukan dengan berdasarkan kemiripan. Pengukuran jarak kemiripan menggunakan city block distance. Data yang digunakan sebanyak 5 sampel untuk masing-masing kategori cabai yaitu cabai besar, cabai rawit, cabai keriting, dan paprika. Hasil pengujian sistem identifikasi citra cabai menunjukkan tigkat akurasi sebesar $93 \%$. Ukuran citra cabai adalah 10x10 piksel, dengan menggunakan metode klasifikasi lorentzian distance. Hasil akurasi paling rendah adalah $57 \%$ pada ukuran citra citra cabai 20x15 dengan menggunakan metode klasifikasi gower distance. Dengan metode 
ekstraksi ciri citra cabai dalam bentuk vektor ciri yang diperoleh dari citra cropping dan jarak city block distance.

Nur dkk [6] melakukan penelitian dengan objek citra Jahe (zingiber officinale). Penelitian ini membahas tentang pengklasifikasian jenis-jenis jahe, yaitu jahe merah, jahe gajah dan jahe emprit. Proses klasifikasi dalam penelitian ini adalah menggunakan pengurangan rerata citra sampel dengan vektor dan histogram citra uji dengan membandingkan nilai minimum dari metrik tersebut. Pengujian unjuk kerja sistem dilakukan dengan melakukan variasi ukuran citra 60x40, 30x20, 15x10 dan 10x10. Hasil pengujian identifikasi citra jahe menunjukkan tingkat akurasi yang tinggi sebesar 81,67\% pada ukuran citra yaitu 15x10 menggunakan ekstraksi ciri vektor dan teknik klasifikasi metode jarak Czekanowski.

Hendarko dkk [7], melakukan sebuah penelitian identifikasi objek melalui citranya. Objek pengidentifikasian adalah citra sidik jari dengan menggunakan alih ragam dan jarak Euclidean [8]. Penelitian mereka menunjukkan hasil yang cukup baik, ini dibuktikan dengan prosentase keberhasilan mencapai $91 \%$ pada wavelet jenis daubiechies_8 untuk 100 citra uji. Pada pengujian jenis wavelet terbaik (daubechies 8) dengan 10,5 dan 1 basisdata mengalami penurunan prosentase tingkat keberhasilan pengenalan yaitu dari $91 \%, 90 \%$, dan $83 \%$.

Penelitian prediksi yang berkaitan dengan kelapa telah juga dilakukan. Salah satu penelitian dilakukan prediksi volume santan buah kelapa berdasarkan warna kecoklatan dari kulit ari buah dengan menggunakan metode analisis warna [9]. Cara kerja dari sistem mereka adalah buah kelapa yang telah dikupas dari batoknya diambil citranya, lalu dengan citra tersebut akan dijadikan input pada pengenalan pola, lalu dilakukan identifikasi, sehingga dapat diketahui karakteristik yang ada pada setiap buah kelapa. Tingkat akurasi sistem mereka secara keseluruhan adalah $80 \%$ dengan waktu komputasi 44,95 sekon [9]. Disamping itu pernah juga dilakukan penelitian untuk klasifikasi ukuran buah kelapa yaitu buah kelapa hibrida [10]. Mereka meneliti untuk membangun sebuah sistem cerdas klasifikasi buah kelapa dengan menggunakan metode backpropagation berdasarkan pada warna dan ukuran dari kelapa tersebut. Hasil dari proses klasifikasi adalah informasi mengenai, apakah termasuk muda, matang atau tua. Penelitian lain yang berkaitan dengan klasifikasi objek kelapa dilakukan juga oleh Abdullah, dkk [11]. Penelitian ini menggunakan metode lain yaitu NMC dalam mengklasifikasikan kualitas kopra. Penelitian ini Pengklasifikasiannya tidak hanya berpatokan dari warna saja tapi juga tekstur.

Penelitian ini berbeda dengan penelitian yang telah dilakukan sebelumnya. Penelitian ini mengklasifikasikan santan kelapa berdasarkan kualitasnya. Klasifikasi dibagi menjadi 3 kelas santan kelapa, yaitu santan murni, santan sedang dan santan cair. Klasifikasi berdasarkan pada nilai RGB pada citra. Algoritma klasifikasi yang digunakan adalah nearest mean classifier (NMC).

\section{METODE PENELITIAN}

Akuisisi citra dilakukan dengan menggunakan 3 macam kamera smartphone yaitu Xiaomi Mi 8 Lite, Oppo F7, dan Samsung J3 Pro. Pengambilan citra dilakukan dengan jarak $20 \mathrm{~cm}$. Setelah objek ditangkap dilakukan proses digitalisasi menjadi citra digital oleh martphone. Ada tiga kategori santan yang diambil yaitu santan murni, santan sedang dengan campuran $25 \%$ air, dan santan cair dengan tambahan 50\% air. Masing-masing kategori terdiri dari 45 sampel, sehingga total citra hasil akuisisi adalah sebanyak 135 citra. Citra diolah menjadi citra warna 24 bit dengan format Jpeg (jpg) dengan ukuran 640 x 480 piksel. Setelah itu, dilakukan proses ekstraksi fitur pada 90 citra sampel. Fitur yang digunakan sebagai pembeda adalah warna red, green dan blue (RGB) [12].

Ekstraksi fitur citra dilakukan sehingga dihasilkan vektor fitur nilai RGB. Sebelum dilakukan klasifikasi atau perhitungan jarak vektor dilakukan normalisasi RGB. Model normalisasi RGB [13] memiliki 3 komponen yaitu, R, G, B, yang merepresentasikan persentase dari sebuah piksel pada citra digital. Nilai-nilai tersebut mengikuti persamaan (1) di bawah ini:

$$
\mathrm{r}=\frac{R}{R+G+B}, g=\frac{G}{R+G+B}, b=\frac{B}{R+G+B}
$$

Vektor fitur disimpan di dalam database fitur citra. Masing-masing fitur citra diberi label untuk membedakan kategori yang satu dengan yang lain. 
Pada tahap pengembangan sistem dilakukan mulai dari perancangan dan implementasi sistem. Pada perancangan sistem dihasilkan arsitektur sistem, yang menggambarkan sistem yang akan dibuat. Pada implementasi sistem dilakukan penerapan coding sistem prediksi kualtas santan berbasis android. Pada tahapan ini ditentukan sistem operasi, bahasa pemrograman dan sistem manajemen basis data yang digunakan.

Proses klasifikasi dilakukan dengan menggunakan algoritma NMC. NMC melakukan klasifikasi sembarang objek berdasarkan kemiripan. Kemiripan diukur dengan menggunakan jarak vektor euclidean distance [8] menggunakan persamaan (2). Selanjutnya hasil klasifikasi didasarkan atas jarak terdekat vektor fitur objek dengan centroid. Citra dikatakan mirip apabila memiliki jarak yang paling dekat atau nilainya paling kecil. Ouput yang dihasilkan adalah label nama kelas atau kategori objek.

$$
\operatorname{Dist}(i, k)=\sqrt{\sum_{i=j}^{D}\left(i_{j}-k_{j}\right)^{2}} .
$$

Dengan dist (i,k) adalah jarak euclidean antara vektor i dan vektor $\mathrm{k}$

$\mathrm{ij}=$ komponen $\mathrm{ke} \mathrm{j}$ dari vektor $\mathrm{i}$

$\mathrm{kj}=$ komponen $\mathrm{ke} \mathrm{j}$ dari vektor $\mathrm{k}$

$\mathrm{D}$ adalah jumlah komponen pada vektor I dan vektor k.

Pengujian sistem menggunakan 3 buah kamera smartphone dengan berbeda merek, 1 diantaranya adalah kamera smartphone yang juga digunakan untuk pelatihan. Penggunaan 3 buah kamera smartphone yang berbeda untuk pengujian ini diperlukan untuk mengetahui sejauh mana sistem tetap dapat mengenali citra input, meskipun pada kenyataannya beda kamera smartphone berbeda pula jenis lensa dan software pengolah kamera. Tiga buah kamera smartphone andoid yang digunakan adalah: (1) Kamera 1 : Xiaomi Mi 8 Lite, (2) Kamera Oppo F7, (3) Samsung Galaxy J3 Pro. Evaluasi sistem dilakukan untuk mengetahui kinerja klasifikasi dengan menggunakan metode holdout [14]. Pada metode holdout, data set asli yang sudah diketahui label kelasnya dibagi menjadi dua bagian, yaitu data yang digunakan untuk membangun data pengetahuan sistem dan data yang digunakan untuk menguji kinerja sistem. Proporsi antara kedua jenis data tersebut adalah 2 berbanding 1 . Data set asli yang terdiri atas 135 citra berlabel dibagi menjadi dua bagian. Bagian pertama terdiri atas 90 citra (2/3 dari total data) digunakan sebagai data sampel yang disimpan dalam basis data pengetahuan sedangkan 45 citra (1/3 dari total data) digunakan sebagai data uji. Baik citra yang diprediksi benar maupun yang diprediksi salah, direkap dalam matriks konfusi [15]. Selanjutnya dilakukan uji akurasi sistem menggunakan persamaan (3). Setelah dilakukan eavaluasi dengan metode holdout maka diperoleh akurasi sistem.

$$
\text { Akurasi }=\frac{\text { jumlah data yang diprediksi benar }}{\text { jumlah prediksi yang dilakukan }}
$$

\section{HASIL DAN PEMBAHASAN}

Pada 90 buah sampel yang terdiri dari 3 (tiga) kategori dilakukan ekstraksi fitur. Setiap kategori diwakili oleh rata-rata vektor fitur sampel yang menjadi titik pusat kelas (centroid). Sehingga ada tiga centroid sesuai dengan jumlah kategori santan. Setiap centroid diberikan label kelas kategori sebagaimana terlihat pada Tabel 1 .

Tabel 1. Centroid Vektor Fitur Citra Sampel sebelum Normalisasi

\begin{tabular}{|l|l|l|l|}
\hline \multicolumn{1}{|c|}{ Nama Kelas } & Mean Red & Mean Green & Mean Blue \\
\hline Santan Murni & 166.7 & 166.9667 & 163.4333 \\
\hline Santan Sedang & 167.2 & 167.7 & 163.5667 \\
\hline Santan Cair & 164.7 & 165.2333 & 161.2667 \\
\hline
\end{tabular}

Tabel 2 memperlihatkan centroid fitur citra sampel masing-masing kelas dengan labelnya setelah proses normalisasi. 
Tabel 2. Rata-rata Vektor Fitur Citra Sampel setelah Normalisasi

\begin{tabular}{|l|c|c|c|}
\hline \multicolumn{1}{|c|}{ Nama Kelas } & Mean Red & Mean Green & Mean Blue \\
\hline Santan Murni & 0.3354 & 0.3359 & 0.3288 \\
\hline Santan Sedang & 0.3354 & 0.3364 & 0.3281 \\
\hline Santan Cair & 0.3353 & 0.3364 & 0.3283 \\
\hline
\end{tabular}

Pada pengembangan sistem, dibuat dua buah sub sistem, yaitu subsistem pembentuk basis data pengetahuan dan sub sistem pemrosesan klasifikasi. Pada sub sistem pembentuk basis data pengetahuan dilakukan perekaman fitur citra sampel. Pada sub sistem pemroses klasifikasi dilakukan proses klasifikasi. Gambar 2 merupakan arsitektur sistem aplikasi klasifikasi santan kelapa. ini bekerja dengan hardware dan pengimplementasiannya. Terdapat dua sub sistem yang ditandai batas antara bagian kiri dan kanan. Bagian sebelah kiri adalah sub sistem pembentuk kelas, sedangkan sebelah kanan adalah sub sistem klasifikasi.

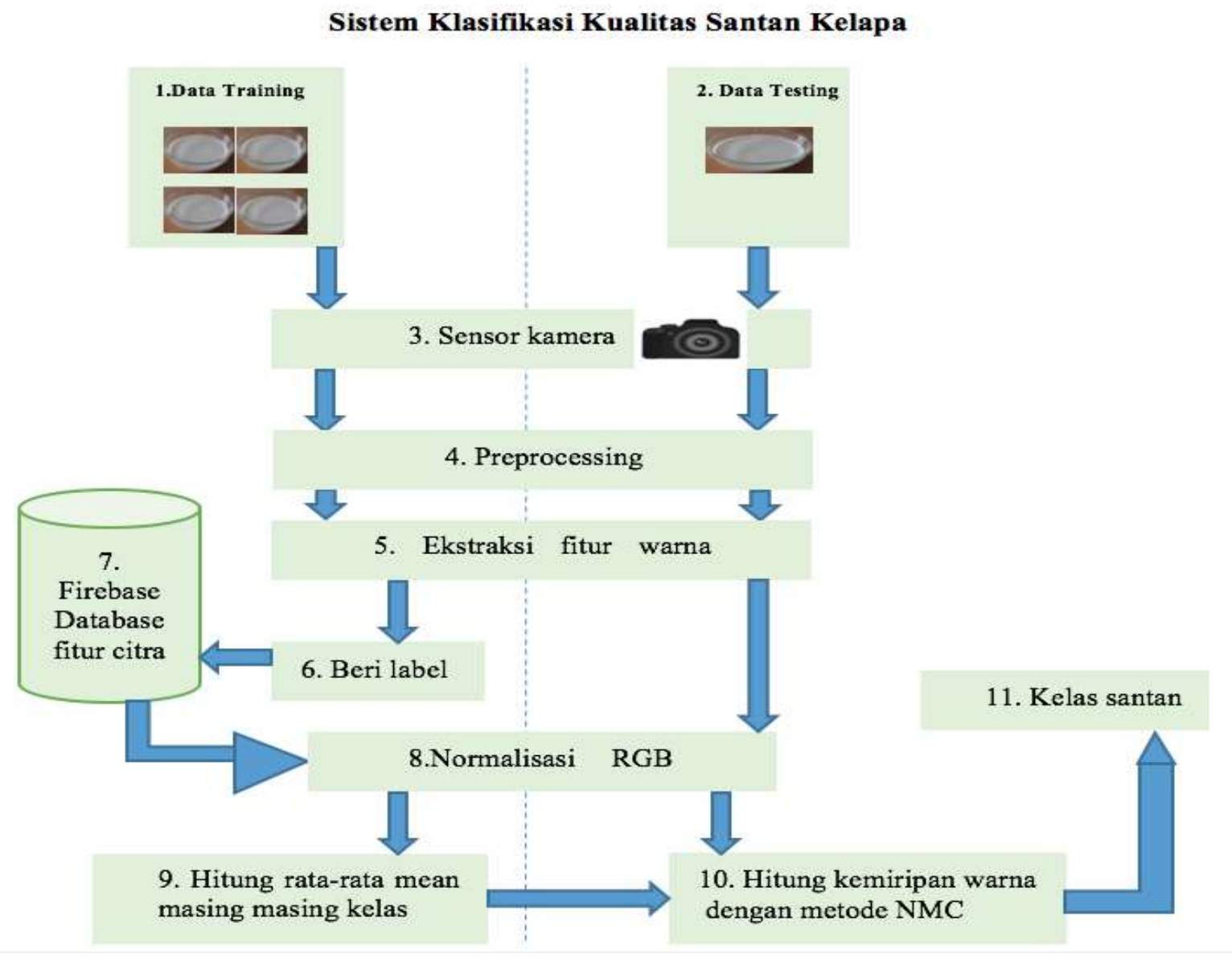

\section{Gambar 2. Arsitektur Sistem Klasifikasi Santan Kelapa}

Sensor kamera smartphone digunakan untuk proses akuisisi citra. Setelah citra digital diperoleh dilakukan preprocessing. Preprocessing yang dilakukan adalah pengolahan citra meliputi perbaikan citra dan perubahan size dan resolusi citra. Semua data citra yang diambil resolusinya diubah menjadi 640x480 piksel. Selanjut pada citra dilakukan proses ekstraksi fitur. Setiap vektor fitur citra dihitung mean kelas (centroid) dan diberikan label atau kategori. Masing-masing kategori diwakili oleh satu vektor fitur, yang merupakan rata-rata fitur sampel pada kategori tersebut.

Pada fase pembentukan kelas setiap vektor fitur centroid atau mean kelas disimpan dalam basis data fitur citra sebagai knowledge base. Pada fase klasfikasi dilakukan klasifikasi objek yang belum diketahui kategorinya. Sebagaimana halnya proses akuisisi yang dilakukan pada fase pembentukan kelas, maka hal ini juga diterapkan pada penangkapan citra uji. Selanjutnya proses klasifikasi citra 
dilakukan dengan pendekatan kemiripan, yaitu dengan menghitung jarak vektor antara vektor fitur yang ada dalam basis data dengan vektor fitur objek yang belum diketahui.

Untuk menentukan kategori objek yang belum diketahui dilakukan proses klasifikasi. Proses klasifikasi menggunakan nearest mean classifier (NMC). NMC melakukan klasifikasi sebarang objek yang tidak diketahui ke dalam suatu kelas terdekat, yaitu objek diklasifikasi berdasarkan kemiripannya dengan sampel. Objek yang tidak diketahui kategorinya diekstraksi fiturnya terlebih dahulu. Vektor fitur objek tersebut diukur kemiripannya dengan centroid yang sudah tersimpan dalam database.

Basis data yang digunakan adalah Firebase, yang menyimpan data secara on line. Basis data ini memiliki kelebihan yaitu bersifat real time. Firebase memiliki produk utama, yaitu menyediakan database realtime dan backend sebagai layanan (Backend as a Service). Layanan ini menyediakan pengembang aplikasi API yang memungkinkan aplikasi data yang akan disinkronisasi di klien dan disimpan di cloud Firebase ini. Firebase menyediakan library untuk berbagai client platform yang memungkinkan integrasi dengan Android, iOS, JavaScript, Java, Objective-C dan Node aplikasi Js dan dapat juga disebut sebagai layanan DbaaS (database as a service) dengan konsep realtime. Firebase digunakan untuk mempermudah dalam penambahan fitur-fitur yang akan dibangun oleh developer.

Beberapa diagram UML digunakan dalam proses perancangan sistem ini antara lain: activity diagram, use case, sequen diagram.

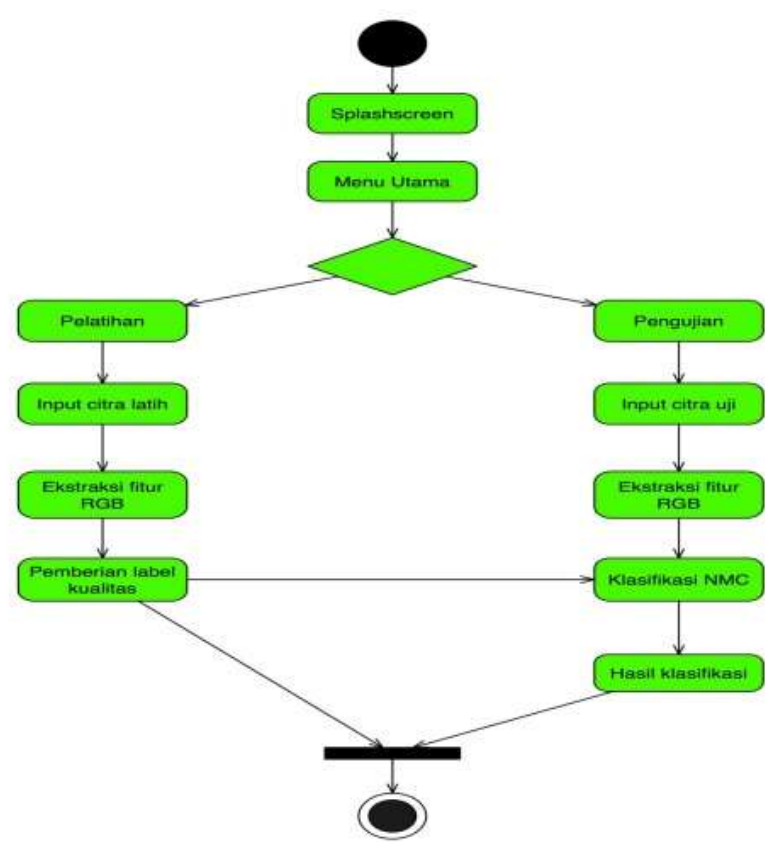

Gambar 3. Activity Diagram Sistem

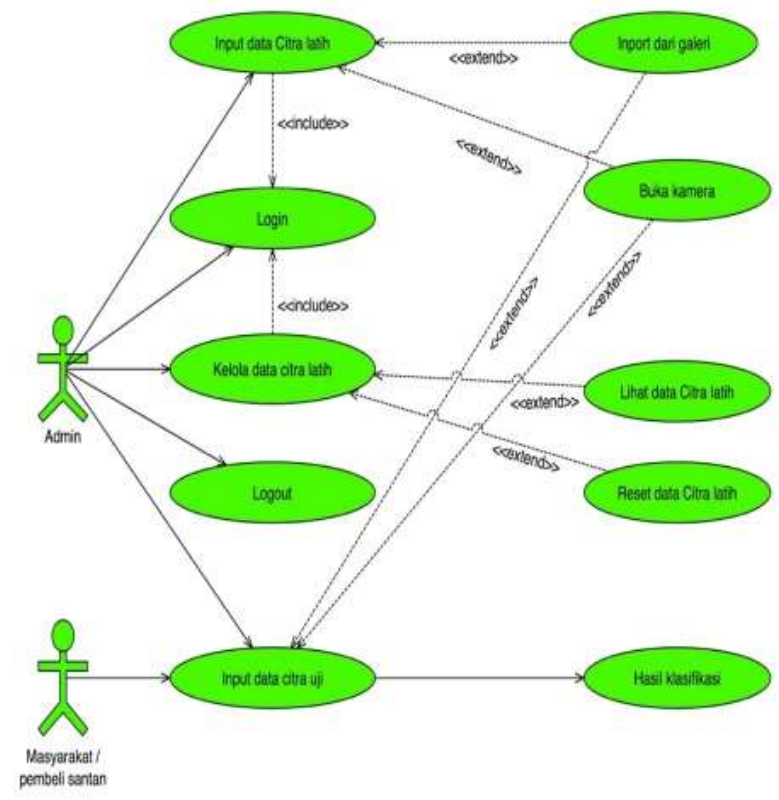

Gambar 4. Use Case Sistem

Pada Gambar 3 ditunjukkan activity diagram sistem. Terlihat alur sistem klasifikasi santan kelapa melalui beberapa tahapan, sehingga didapatkan hasil dari klasifikasi berupa label kelas. Pada Gambar 4 ditunjukkan diagram use case sistem. Terlihat bahwa sistem klasifikasi memiliki dua aktor yang satu merupakan admin dan satunya lagi merupakan user. Beberapa proses seperti input citra sampel, ekstraksi fitur citra sampel, pemberian label citra sampel, simpan data sampel, input citra uji, ekstraksi citra uji, dan hasil klasifikasi. Pada sistem ini admin dapat melakukan proses rekam data sampel dengan melakukan login dan input citra sampel terlebih dahulu. Tetapi user yang menggunakan sistem ini hanya dapat melakukan proses deteksi saja yang terdiri dari input citra uji, ektraksi citra uji dan mendapatkan output berupa hasil prediksi. 


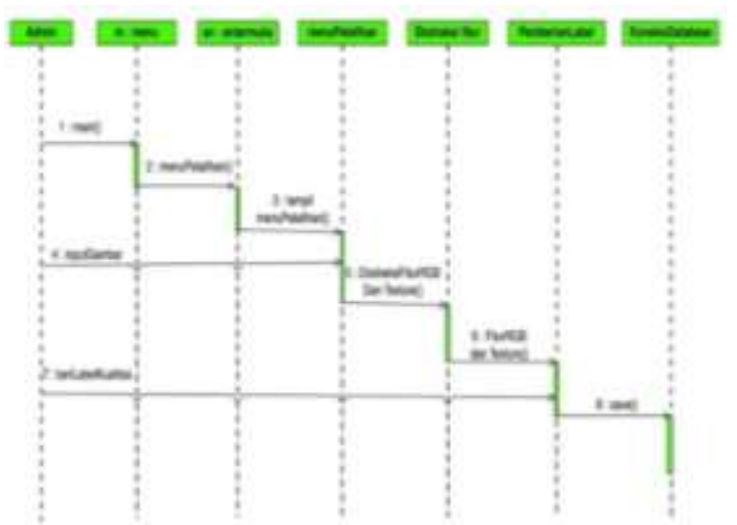

Gambar 5. Diagram Sekuen Sub Sistem Pembentuk Basis Data

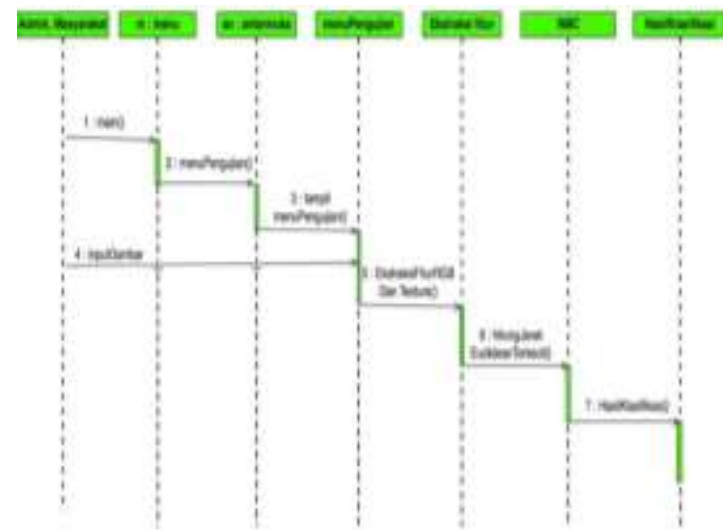

Gambar 6. Diagram Sekuen Sub Sistem Klasifikasi

Pada Gambar 5 yang merupakan diagram sekuen sub sistem pembentuk basis data dijelaskan alur kerja sistem dengan metode NMC, mulai dari memilih menu pelatihan, input gambar citra pelatihan sampai proses menyimpan fitur warna RGB yang telah diberi label ke dalam database. Pada Gambar 6 yang merupakan diagram sekuen sub sistem klasifikasi dijelaskan alur kerja sistem, mulai dari memilih menu pengujian, input citra uji, proses klasifikasi berdasarkan fitur warna RGB, sampai menampilkan hasil dari klasifikasi kelas kualitas santan kelapa.

Implementasi sistem prediksi kualitas santan yakni membangun antar muka ke dalam beberapa tampilan antar muka program, tampilan awal, halaman antar muka menu utama, antar muka dashboard admin, dan halaman hasil uji. Perangkat lunak yang digunakan pemograman Java, Android Studio dan sistem operasi MacOS High Sierra versi 10.13.3.

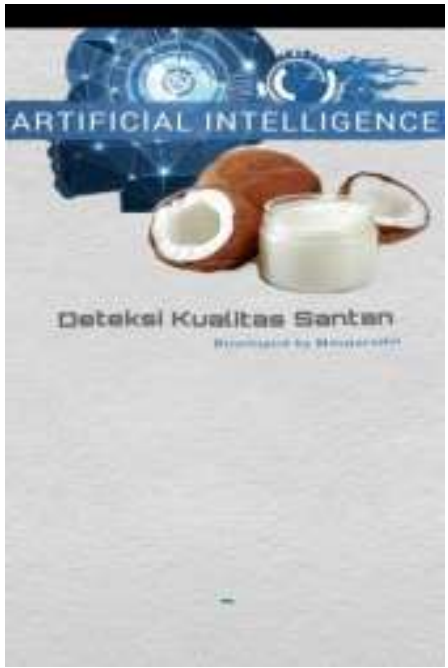

Gambar 7. Halaman Splashscreen
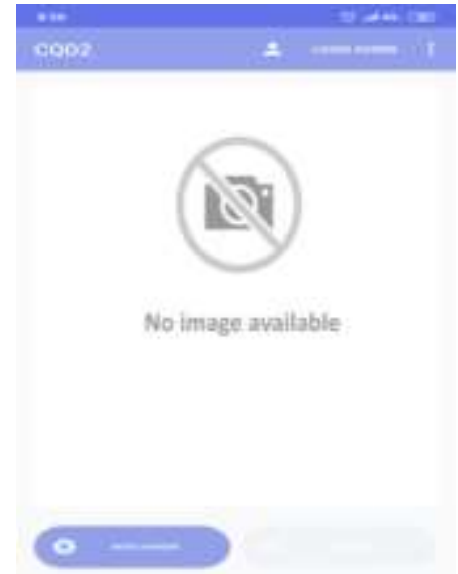

\section{Gambar 8. Antarmuka Menu Utama}

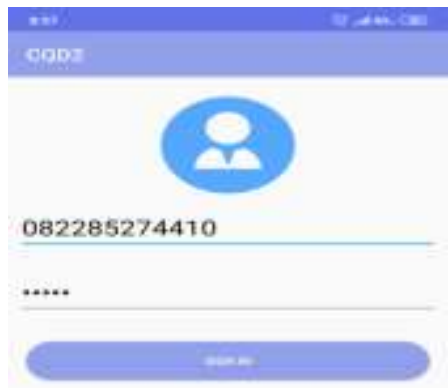

\section{Gambar 9. Antarmuka Login Admin}

Pada Gambar 7 ditunjukkan tampilan awal pengenalan aplikasi kepada pengguna. ini adalah tampilan paling awal sebelum masuk ke halaman menu utama. Antar muka menu utama adalah tampilan yang dihadapkan pada user atau admin apakah ingin melakukan pengujian atau melakukan login sebagai admin. Pada Gambar 8 ditampilkan halaman menu utama yang disajikan untuk user ataupun admin. terdapat tombol login jika admin ingin masuk ke dashboard admin. Terdapat pula tombol buka kamera untuk melakukan pengujian langsung dengan membuka kamera untuk menangkap citra. Pada Gambar 9 ditampilkan antarmuka login admin yang berfungsi untuk sebuah gerbang bagi admin untuk masuk ke dashboard admin, dengan harus terlebih dahulu memasukkan nomor handphone dan password. Dengan menginputkan nomor handphone dan password yang telah terdaftar pada database maka user bisa masuk sebagai admin. 


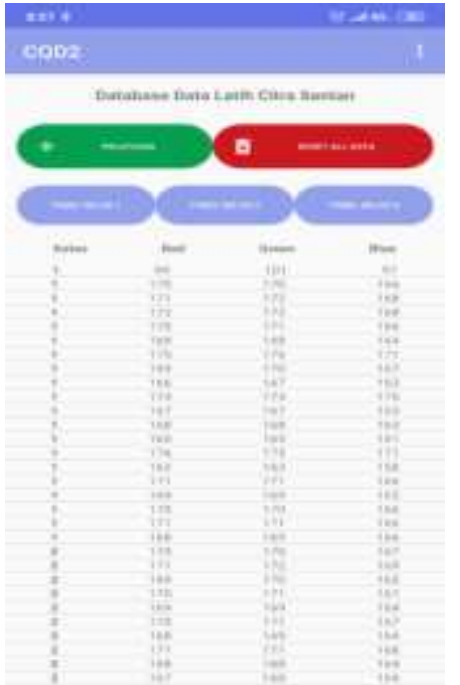

Gambar 10. Antarmuka

Dashboard Admin

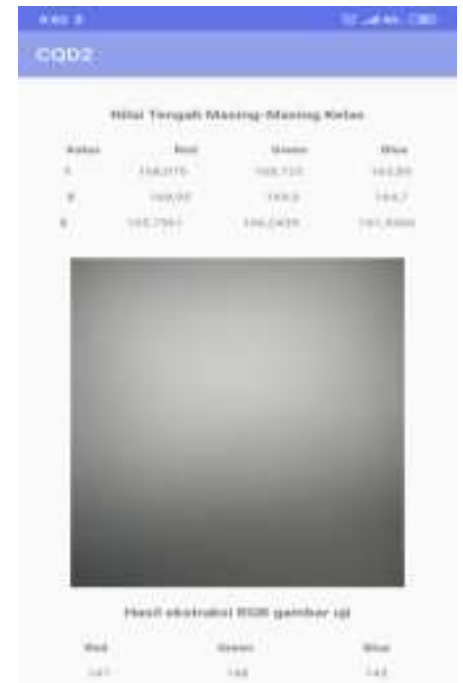

Gambar 11. Hasil Ekstraksi Citra Uji

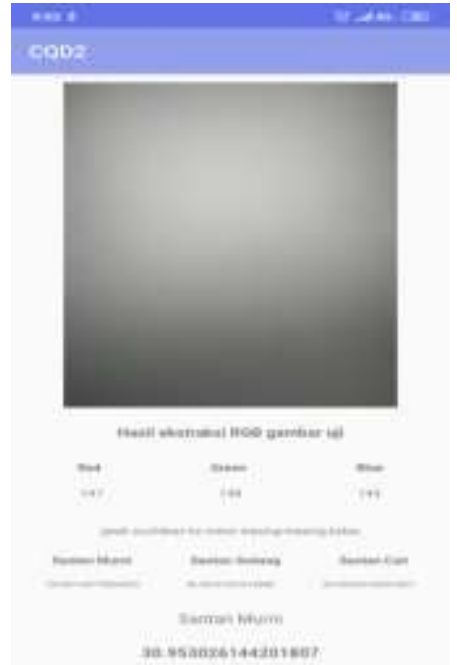

Gambar 12. Hasil Prediksi

Pada Gambar 10 ditampilkan antar muka dashboard admin untuk melihat tabel masing-masing kelas berikut dengan total dan average-nya. Gambar 11 di atas menampilkan semua data sampel yang sudah diinputkan ke basis data. Terdapat beberapa tombol pada tampilan ini yaitu pelatihan, reset all data, tabel kelas 1, tabel kelas 2 dan tabel kelas 3. Pada Gambar 7 ditujukkan hasil ekstraksi data uji dan Gambar 12 ditunjukkan hasil prediksi.

Pengujian diperlukan untuk mengetahui sampai sejauh mana kinerja sistem. Melalui proses pengujian dapat diketahui sejauh mana akurasi sistem. Pengujian sistem menggunakan 3 buah kamera smartphone dengan berbeda merek, 1 diantaranya adalah kamera smartphone yang juga digunakan untuk pelatihan. Penggunaan 3 buah kamera smartphone yang berbeda untuk pengujian ini diperlukan untuk mengetahui sejauh mana sistem tetap dapat mengenali citra input, meskipun pada kenyataannya beda kamera smartphone berbeda pula jenis lensa dan software pengolah kamera. Tiga buah kamera smartphone andoid yang digunakan adalah: (1) Kamera 1 : Xiaomi Mi 8 Lite, (2) Kamera Oppo F7, (3) Samsung Galaxy J3 Pro. Evaluasi sistem dilakukan untuk mengetahui kinerja klasifikasi dengan menggunakan metode holdout [14]. Pada metode holdout, data set asli yang sudah diketahui label kelasnya dibagi menjadi dua bagian, yaitu data yang digunakan untuk membangun data pengetahuan sistem dan data yang digunakan untuk menguji kinerja sistem. Proporsi antara kedua jenis data tersebut adalah 2 berbanding 1 . Data set asli yang terdiri atas 135 citra berlabel dibagi menjadi dua. Bagian pertama terdiri atas 90 citra (2/3 dari total data) digunakan sebagai data sampel yang disimpan dalam basis data pengetahuan sedangkan 45 citra (1/3 dari total data) digunakan sebagai data uji. Hasil prediksi direkap dalam matriks konfusi [15]. Selanjutnya dilakukan uji akurasi sistem menggunakan persamaan (3). Setelah dilakukan eavaluasi dengan metode holdout maka diperoleh akurasi sistem. Tabel 4 menunjukkan matriks konfusi, menggunakan ketiga jenis kamera.

Tabel 4. Hasil Pengujian Sistem

\begin{tabular}{|c|c|c|c|c|c|}
\hline \multirow{2}{*}{ No } & \multirow{2}{*}{$\begin{array}{c}\text { Jenis } \\
\text { Kamera }\end{array}$} & \multirow{2}{*}{$\begin{array}{c}\text { Jumlah Citra } \\
\text { Uji }\end{array}$} & $\begin{array}{c}\text { Klasifikasi } \\
\text { Dikenali } \\
\text { Benar }\end{array}$ & $\begin{array}{c}\text { Dikenali } \\
\text { Salah }\end{array}$ & Akurasi \\
\hline 1 & $\begin{array}{c}\text { Xiaomi Mi } \\
8 \text { Lite }\end{array}$ & 45 & 39 & 6 & $\frac{39}{45} \times 100=86,66 \%$ \\
\hline 2 & Oppo F7 & 45 & 27 & 18 & $\frac{27}{45} \times 100=60 \%$ \\
\hline 3 & Kamera 3 & 45 & 21 & 24 & $\frac{21}{45} \times 100=46,66 \%$ \\
\hline
\end{tabular}


Jadi sistem pengklasifikasian kualitas santan kelapa ini memiliki akurasi terbaik pada kamera Xiaomi Mi yaitu 86,66\%.Untuk melihat gambaran ilustrasi dari akurasi pengujian sistem dengan menggunakan 3 buah kamera smart phone dapat dilihat pada diagram batang di bawah ini:

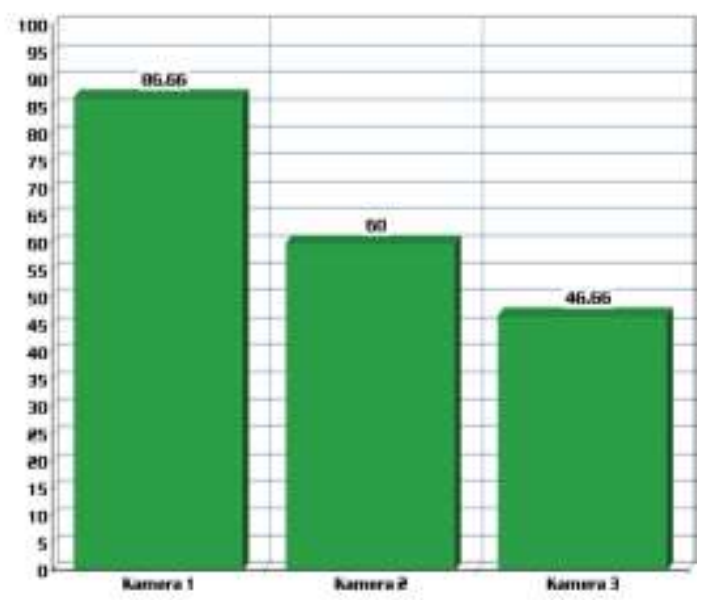

\section{Gambar 8. Diagram Batang Akurasi Pengujian Sistem}

Berdasarakan Gambar 8, Kamera Xiaomi Mi memiliki akurasi 86,66\%, tertinggi dibanding dua kamera lainnya, karena kamera ini adalah kamera yang digunakan untuk merekam citra sampel. Penggunaan lensa dan pencahayaan menjadi faktor penentu dalam proses pengklasifikasian, lensa kamera smart phone yang digunakan pada saat pengambilan sampel menghasilakn akurasi yang lebih jika digunakan dalam melakukan prediksi.

\section{KESIMPULAN DAN SARAN}

Berdasarkan penelitian yang telah dilakukan diambil kesimpulan bahwa metode mearest mean classifier dapat digunakan dalam melakukan prediksi kualitas santan kelapa dengan menggunakan aplikasi berbasis android. Parameter warna RGB dapat digunakan sebagai ciri pembeda dalam klasifikasi santan. Sistem dapat melakukan klasifikasi santan kelapa dengan akurasi yang berbeda-beda, tergantung kepada jenis kamera. Ketelitian terbaik pada tiga jenis kamera adalah 86,66\%, Tingkat akurasi klasifikasi kualitas santan sangat tergantung dengan jenis hardware kamera smartphone, software pengolah kamera smartphone dan pencahayaan. Beberapa saran untuk pengembangan lebih lanjut terhadap penelitian ini yaitu, penambahan alat bantu sensor tambahan yang dapat memeriksa kekentalan santan kelapa untuk proses klasifikasi yang lebih akurat dan lebih baik. Penelitian ini dapat dikembangkan lagi dengan melakukan penelitian pendeteksian kualitas santan kelapa dengan menggunakan metode lainnya.

\section{REFERENSI}

[1] M. Bhat, "Digital Image Processing," Int. J. Sci. Technol. Res., vol. 3, no. 1, pp. 272-276, 2014.

[2] E. Santucci, "Quantum Minimum Distance Classifier," Entropy, vol. 19, no. 659, pp. 1-14, 2017.

[3] Claudio Cusano, P. Napoletano, and R. Schettini, "Combining multiple features for color texture classification," J. Electron. Imaging, vol. 25, no. 6, pp. 1-9, 2016.

[4] C. Khawas and P. Shah, "Application of Firebase in Android App Development-A Study," Int. J. Comput. Appl., vol. 179, pp. 49-53, 2018.

[5] N. T. Anggraeni, "Sistem Identifikasi Citra Jenis Cabai ( Capsicum Annum L .) Menggunakan Metode Klasifikasi City Block," J. Sarj. Tek. Inform., vol. 1, no. 2, pp. 409-418, 2013.

[6] S. Nur, D. Sari, A. Fadlil, and P. Soepomo, "Sistem Identifikasi Citra Jahe (Zingiber Officinale) Menggunakan Metode Jarak Czekanowski," J. Sarj. Tek. Inform., vol. 2, no. 2, pp. 307-316, 2014.

[7] G. Hendarko, A. Hidayatno, and R. R. Isnanto, "Identifikasi Citra Sidikjari Menggunakan 
Alihragam Wavelet dan Jarak Euclidean,” pp. 1-7, 2010.

[8] A. Bonvard, S. Houcke, R. Gautier, and M. Marazin, "Classification Based on Euclidean Distance Distribution for Blind Identification of Error Correcting Codes in Noncooperative Contexts," IEEE Trans. Signal Process., vol. 66, pp. 2572-2583, 2018.

[9] A. Budiastrini, A. Rizal, and R. D. Atmaja, "Prediksi Volume Santan Kelapa menggunakan Android dengan Metode Analisis Warna Berbasis Pengolahan Citra Digital," 2013.

[10] Abdullah and Usman, "Sistem cerdas untuk klasifikasi buah kelapa menggunakan metode backpropagation," Selodang Mayang, vol. 2, no. 2, pp. 87-94, 2016.

[11] Abdullah, Usman, and M. Efendi, "Sistem Klasifikasi Kualitas Kopra berdasarkan Warna dan tekstur Menggunakan Metode Nearest Classifier (NMC)," J. Teknol. Inf. dan Ilmu Komput., vol. 4, no. 4, pp. 297-303, 2017.

[12] Z. Alqadi, M. Khrisat, A. Hindi, and M. Dwairi, "Features Analysis of RGB Color Image based on Wavelet Packet Information," 2020.

[13] S. Kolkur, D. Kalbande, P. Shimpi, C. Bapat, and J. Jatakia, "Human Skin Detection Using RGB, HSV and YCbCr Color Models," in Advances in Intelligent Systems Research, 2017, vol. 137, pp. 324-332.

[14] P. Galdi and R. Tagliaferri, "Data Mining: Accuracy and Error Measures for Classification and Prediction," in Reference Module in Life Sciences, no. January, Elsevier, 2018, pp. 1-14.

[15] J. M. Kirimi and C. A. Moturi, "Application of Data Mining Classification in Employee Performance Prediction,” Int. J. Comput. Appl., vol. 146, no. 7, pp. 28-35, 2016. 